\title{
Hubungan Daya Turbin Angin Berbentuk Propeller 5 Blade Terhadap Beban Tower Penyangganya
}

\author{
Wardoyo \\ DosenTeknik Mesin Universitas Negeri Jakarta \\ wardoyo_mt@yahoo.co.id
}

\begin{abstract}
ABSTRAK
Penggunaan energi alternatif yang ramah lingkungan (Green Energy) merupakan topik utama yang mulai banyak dibahas dewasa ini. Fenomena ini disebabkan oleh semakin sedikitnya sumber energi fosil yang menuntut manusia mencari sumber-sumber energi baru dan terbarukan untuk menggantikan energi konvensional tersebut. Salah satu sumber energi yang berkembang saat ini ialah energi angin, yang mulai dimanfaatkan untuk menghasilkan listrik ataupun mengkonversinya ke energi mekanik untuk keperluan lain. Salah satu alat yang digunakan untuk memanfaatkan energi angin adalah turbin angin. Indonesia, negara kepulauan yang 2/3 wilayahnya adalah lautan dan mempunyai garis pantai terpanjang di dunia merupakan wilayah potensial untuk pengembangan pembanglit listrik tenaga angin. Semakin besar daya yang dihasilkan turbin maka akan dibutuhkan tower turbin yang mampu menerima beban yang besar. Jumlah beban pada tower turbin ini dibutuhkan sebagai referensi untuk mendesain konstruksi tower turbin angin.

Penelitian ini bertujuan mencari hubungan antara daya yang dihasilkan turbin angin dengan beban momen lengkung yang diterima tower turbin. Daya turbin diperoleh dari gaya lift pada propeller yang dilewati angin, sementara beban yang diterima tower turbin diperoleh dari gaya drag pada propeller yang dilalui angin.

Hasil penelitian ini menunjukan bahwa dengan variasi kecepatan udara 5 - 8 meter/detik, momen lengkung yang diterima oleh tiang penyangga turbin angin hanya sebesar 30,13\% dari momen puntir yang dihasilkan turbin. Pada kecepatan udara $5 \mathrm{~m} / \mathrm{s}$, torsi pada poros 70,899 Nm, momen lengkung tiang penyangga 21,358 Nm, sementara pada kecepatan udara $8 \mathrm{~m} / \mathrm{s}$ torsi pada poros 181,501 Nm, momen lengkung tiang penyangga 54,678 Nm.
\end{abstract}

Kata Kunci : Wind Turbine, Lift, Drag, Propeller, 5 Blade

\section{Pendahuluan}

\subsection{Latar Belakang}

Penggunaan energi alternatif yang ramah lingkungan (Green Energy) merupakan topik utama yang mulai banyak dibahas dewasa ini. Fenomena ini disebabkan karena perkembangan teknologi yang membutuhkan energi listrik, menyebabkan manusia mencari sumber-sumber energi baru dan energi terbarukan untuk menggantikan energi konvensional. Green Energy merupakan solusi di seluruh dunia untuk melestarikan bumi ini untuk waktu yang lama dikarenakan sumber energi seperti bahan bakar fosil dianggap menyebabkan pemanasan global. Green Energy juga merupakan istilah yang digunakan untuk menggambarkan sumber energi yang dianggap ramah lingkungan dan non-polusi, seperti energi panas bumi, energi angin, energi surya, energi bioethanol, dan energi hidro (air).

Salah satu sumber energi yang berkembang saat ini ialah energi angin, merupakan salah satu energi yang mulai dimanfaatkan untuk menghasilkan listrik ataupun mengkonversinya ke energi mekanik untuk keperluan lain. Salah satu alat yang digunakan untuk memanfaatkan energi angin adalah turbin angin (wind turbine). Menurut data dari asosiasi energi angin dunia (WWEA), Indonesia menempati urutan ke-70 dunia dalam hal sistem konversi energi angin (SKEA) terpasang (WWEA, 2010) ${ }^{1}$. Dalam blueprint pemanfaatan energi Indonesia untuk tahun 2010-2015, Indonesia sudah memasuki periode

\footnotetext{
${ }^{1}$ WWEA, World Wind Energy Report 2010, (Bonn: World Wind Energy Association, 2010), h.19.
} 
pemanfaatan energi angin dengan turbin skala menengah (DJLPE, 2005) ${ }^{2}$.

Indonesia, negara kepulauan yang 2/3 wilayahnya adalah lautan dan mempunyai garis pantai terpanjang di dunia yaitu $\pm 80.791,42$ merupakan wilayah potensial untuk pengembangan pembanglit listrik tenaga angin ${ }^{3}$.

Indonesia merupakan salah satu negara yang belum banyak memanfaatkan energi angin sebagai pembangkit listrik karena karakteristik angin di Indonesia yang cenderung berkecepatan rendah dengan rata-rata per tahun sekitar 5-7 m/s $\mathrm{s}^{4}$. Karakteristik kecepatan angin yang rendah tersebut masih dapat dimanfaatkan dengan menggunakan turbin angin kecepatan rendah.

Dalam memanfaatkan energi angin menggunakan turbin angin, terdapat berbagai faktor yang dapat mempengaruhi kinerja turbin angin tersebut. Salah satu hal yang perlu dipertimbangkan adalah perancangan bilah untuk turbin angin yang meliputi ukuran (jarijari rotor), penampang airfoil, panjang chord, dan sudut serang bilah bilah (angle of attack) (Piggot, 2001) ${ }^{5}$.

\subsection{Tujuan Penelitian}

Penelitian ini bertujuan mencari hubungan antara daya yang dihasilkan turbin angin dengan beban yang diterima tower turbin. Daya turbin diperoleh dari gaya lift pada propeller yang dilewati angin, sementara beban yang diterima tower turbin diperoleh dari gaya drag pada propeller yang dilalui angin.

\section{Tinjuan Pustaka}

\subsection{Potensi angin di Indonesia}

Indonesia merupakan salah satu negara yang belum banyak memanfaatkan energi angin sebagai pembangkit listrik karena karakteristik angin di Indonesia yang cenderung berkecepatan rendah dengan rata-rata sepanjang tahun sekitar 5-7 m/s. Karakteristik kecepatan angin yang rendah tersebut masih dapat dimanfaatkan dengan menggunakan turbin angin kecepatan rendah.

2 DJLPE, Blueprint Pengeloaan Energi Nasional 2005-
2010 (Jakarta: Direktorat Energi dan SDM, 2005), h. 51.

${ }^{3}$ BPPT, Outlook Energi Indonesia 2009, (Jakarta: BPPT Press, 2009), h.7-7.

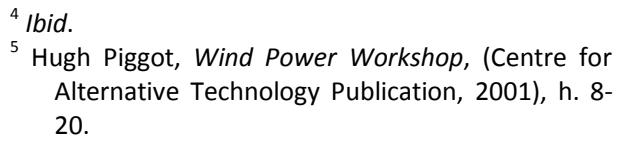

${ }^{5}$ Hugh Piggot, Wind Power Workshop, (Centre for Alternative Technology Publication, 2001), h. 820.

Tabel - 1. Tingkat kecepatan angin 10 meter di atas permukaan tanah. ${ }^{6}$

\begin{tabular}{|c|c|l||}
\hline $\begin{array}{c}\text { Kelas } \\
\text { Angin }\end{array}$ & $\begin{array}{c}\text { Kecepatan } \\
\text { Angin (m/det) }\end{array}$ & \multicolumn{1}{|c|}{ Kondisi Alam di Daratan } \\
\hline 1 & $0.00-0.02$ & \multicolumn{1}{|c|}{--------- } \\
\hline 2 & $0.3-1.5$ & Angin tenang, asap turun ke atas \\
\hline 3 & $1.6-3.3$ & Asap bergerak mengikuti arah angin \\
\hline 4 & $3.4-5.4$ & $\begin{array}{l}\text { Wajah terasa ada angin, daun } \\
\text { bergoyang pelan, petunjuk arah angin } \\
\text { bergerak }\end{array}$ \\
\hline 5 & $5.5-7.9$ & $\begin{array}{l}\text { Debu jalan, kertas beterbangan, ranting } \\
\text { pohon bergoyang }\end{array}$ \\
\hline 6 & $8.0-10.7$ & $\begin{array}{l}\text { Ranting pohon bergoyang, bendera } \\
\text { berkibar }\end{array}$ \\
\hline 7 & $10.8-13.8$ & $\begin{array}{l}\text { Ranting pohon besar bergoyang, air } \\
\text { plumpang bergelombang kecil }\end{array}$ \\
\hline 8 & $13.9-17.1$ & $\begin{array}{l}\text { Ujung pohon melengkung, hembusan } \\
\text { angin terasa di telinga }\end{array}$ \\
\hline 9 & $17.2-20.7$ & $\begin{array}{l}\text { Dapat mematahkan ranting pohon, } \\
\text { jalan berat melawan arah angin }\end{array}$ \\
\hline 10 & $20.8-24.4$ & $\begin{array}{l}\text { Dapat mematahkan ranting pohon, } \\
\text { rumah rubuh }\end{array}$ \\
\hline 11 & $24.5-28.4$ & $\begin{array}{l}\text { Dapat merubuhkan } \\
\text { menimbulkan kerusakan }\end{array}$ \\
\hline 12 & $28.5-32.6$ & Menimbulkan kerusakan parah \\
\hline 13 & $32.7-36.9$ & Tornado \\
\hline
\end{tabular}

kecepatannya, makin cepat angin bertiup maka makin besar kekuatannya. Untuk lebih jelasnya dijelaskan pada tabel kondisi angin dan tingkat kecepatan angin 10 meter di atas permukaan tanah.

Angin kelas 3 adalah batas minimum dan angin kelas 8 adalah batas maksimum energi angin yang dapat dimanfaatkan untuk menghasilkan energi listrik.

\subsection{Faktor Yang Mempengaruhi Kecepatan Angin \\ Kecepatan angin dapat dipengaruhi oleh} beberapa faktor sebagai berikut:

a. Relief Permukaan Bumi. Angin bertiup kencang pada daerah yang reliefnya rata dan tidak ada rintangan. Sebaliknya bila bertiup pada daerah yang reliefnya besar dan rintangannya banyak, maka angin akan berkurang kecepatannya.

b. Ada Tidaknya Tumbuh-tumbuhan. Banyaknya pohon-pohonan akan menghambat kecepatan angin dan sebaliknya, bila pohon-pohonannya jarang maka sedikit sekali memberi hambatan pada kecepatan angin.

c. Tinggi dari Permukaan Tanah. Angin yang bertiup dekat dengan permukaan bumi akan mendapatkan hambatan karena bergesekan

\footnotetext{
${ }^{6}$ Ibid.
} 
dengan muka bumi, sedangkan angin yang bertiup jauh di atas permukaan bumi bebas dari hambatan-hambatan.

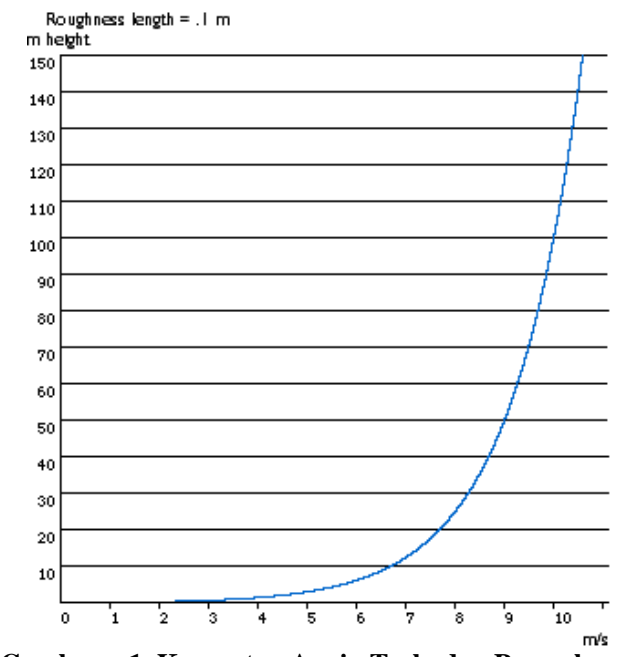

Gambar - 1. Kecepatan Angin Terhadap Permukaan $\operatorname{Tanah}^{7}$

\subsection{Prinsip Konversi Energi Angin}

a. Energi Kinetik Angin

Angin adalah udara yang bergerak. Udara memiliki massa, tetapi densitasnya rendah. Ketika massa bergerak dengan kecepatan tertentu, maka akan menimbulkan energi kinetik. Besarnya energi kinetic yang dihasilkan dapat dihitung dengan rumus berikut ini:

$$
E=\frac{1}{2} m v^{2}
$$

dengan:

$m$ = Massa dari benda yang bergerak (kg)

$v=$ Kecepatan dari benda yang bergerak $(\mathrm{m} / \mathrm{s})$

$E \quad=$ Energi kinetik $(\mathrm{J})$

Jika densitas udara adalah $\rho$, kecepatan udara $V_{\infty}$, sehingga energi kinetik per volume dari udara adalah sebagai berikut:

$$
E_{v}=\frac{1}{2} \rho V_{\infty}^{2}
$$$$
(1)^{9}
$$

dengan:

7 Soren krohn \& Danish wind industry Association, sumber: www.kincirangin.info.

Diakses tanggal 7 April 2012

${ }^{8}$ Vaught Nelson, Wind Energy:Renewable Energy and the Enviorment 2009, (Taylor \& Francis Group, LCC, 2009), h. 13.

${ }^{9}$ Ibid., h.13
$E_{v}=$ Energi kinetik per volume dari udara $\left(\mathrm{J} / \mathrm{m}^{3}\right)$

$\rho=$ Densitas udara $\left(\mathrm{kg} / \mathrm{m}^{3}\right)$

$V_{\infty}=$ Kecepatan angin $(\mathrm{m} / \mathrm{s})$

b. Daya Angin (Power)

Daya angin adalah daya yang dibangkitkan oleh angin tiap luasan, sehingga daya angin dapat digolongkan sebagai energi potensial. Pada dasarnya daya angin merupakan angin yang bergerak per satuan waktu sehingga dapat dirumuskan pada persamaan berikut:

$$
\begin{aligned}
& P_{a}=\frac{1}{2} m V_{\infty}^{2} / t \\
& P_{a}=\frac{1}{2}(\rho \cdot A \cdot d) V_{\infty}^{2} / t \\
& P_{a}=\frac{1}{2} \rho \cdot A \cdot V_{\infty}^{3}
\end{aligned}
$$

dengan:

$$
\begin{aligned}
& P_{a}=\text { Daya angin (Watt) } \\
& V_{\infty}=\operatorname{Kecepatan} \text { angin }(\mathrm{m} / \mathrm{s}) \\
& \rho \quad=\text { massa jenis udara }\left(\mathrm{kg} / \mathrm{m}^{3}\right) \\
& A \quad=\text { Luas penampang kincir }\left(\mathrm{m}^{2}\right)
\end{aligned}
$$

\subsection{Karakteristik Lift dan Drag}

Kincir angin dapat berputar akibat adanya gaya lift yang bekerja secara arah tangensial pada beberapa jarak dari pusat rotor. Selain gaya lift ada juga gaya drag yang bekerja tegak lurus pada arah tangensial gaya angkat. Gaya drag ini berfungsi untuk mengurangi kecepatan kincir yang berputar. Dengan terjadinya putaran maka akan menghasilkan kecepatan sudut. Hal ini dapat dilihat pada gambar berikut.

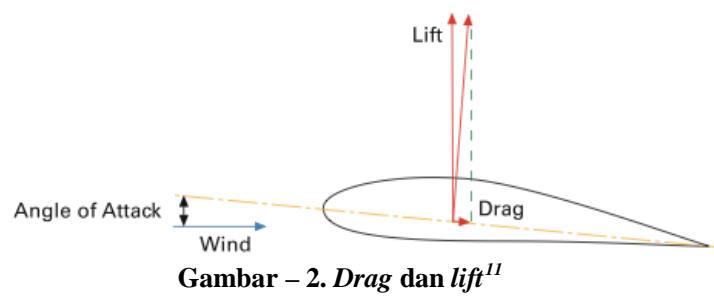

Setiap permukaan airfoil yang mengalir udara terdapat dua gaya yang bekerja yaitu gaya hambat dan gaya angkat. Gaya hambat adalah gaya yang diukur sejajar dengan aliran udara yang menabrak kincir, gaya ini umumnya diperkecil dalam perancangan kincir. Gaya angkat merupakan gaya yang diukur tegak lurus dari aliran udara yang menabrak kincir. Gaya

\section{${ }^{10}$ Ibid., h. 35.}

${ }^{11}$ W.A.M Jansen, op. Cit., h.11. 
hambat dan gaya angkat dapat diukur berdasarkan persamaan berikut:

a. $\operatorname{Drag}$ (Daya hambat)

$D=\frac{1}{2} C_{D} \rho V_{\infty}^{2} A$

Dimana:

$$
\begin{aligned}
& D=\text { Gaya Drag } \\
& C_{D}=\text { Koefisien Gaya Drag } \\
& \rho=\text { massa jenis udara } \\
& A=\text { Luas penampang kincir } \\
& V_{\infty}=\text { Kecepatan angin }
\end{aligned}
$$

b. Lift (Daya angkat)

$L=\frac{1}{2} C_{L} \rho V_{\infty}^{2} A$

Dimana:

$$
\begin{aligned}
& L=\text { Gaya } \text { Lift } \\
& C_{L}=\text { Koefisien Gaya } L i f t \\
& \rho=\text { massa jenis udara } \\
& A=\text { Luas penampang } \\
& V_{\infty}=\text { Kecepatan angin }
\end{aligned}
$$

Besarnya gaya drag dan lift tergantung oleh sudut serang $(\alpha)$. Dalam perancangan airfoil yang terpenting adalah rasio koefisien gaya drag dan koefisien gaya lift harus diminimalisasikan agar didapatkan efek aerodinamika yang seefisien mungkin.

\subsection{Torsi}

Torsi dapat didefinisikan sebagai kemampuan suatu gaya untuk menghasilkan perputaran antara jarak sumbu putar dengan gaya yang bekerja pada titik yang berjarak dari sumbu pusat. Pada kincir angin sumbu horizontal torsi terjadi akibat adanya pengaruh resultan gaya angkat dan gaya dorong yang bekerja sehingga dapat dirumuskan sebagai berikut:

$Q=R F_{r}$

Dimana:

$$
\begin{aligned}
& Q=\text { Gaya torsi } \\
& R=\text { Panjang lengan kincir } \\
& F_{r}=\text { Resultan gaya lift dan drag }
\end{aligned}
$$

\section{Metode Penelitian}

Penelitian ini dimulai dengan pemilihan bentuk airfoil yang dapat menghasilkan lift besar pada kecepatan angin rendah. Setelah dilakukan pengamatan dipilih lima bentuk airfoil yang akan disusun mulia dari ujung propeller hingga pangkalnya sehingga diperoleh

${ }^{12}$ Martin O. L. Hansen, Aerodyanamic of Wind Turbine - Second Edition, 2008 ( United Kingdom dan USA: Earthscan, 2008), h. 48.

13 Ibid., h. 48.

${ }^{14}$ Vaught Nelson, Op. Cit., h. 102. bentuk propeller yang tipis pada ujung namun tebal pada sisi pangkal. Kelima jenis airfoil yang dipilh adalah sebagau berikut:

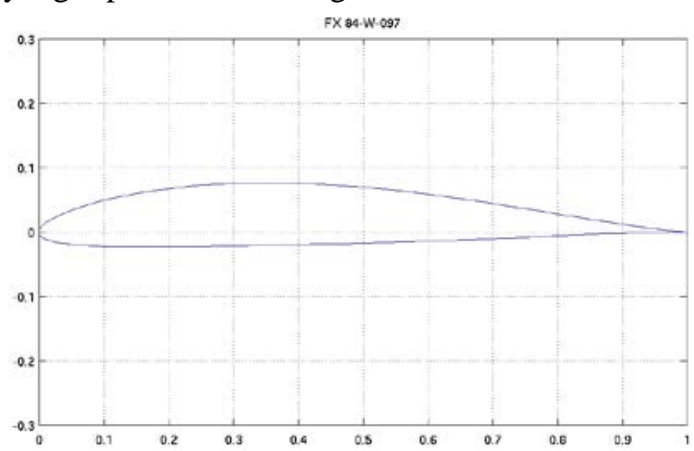

Gambar - 3. Airfoil Wortmann FX 84-W-097

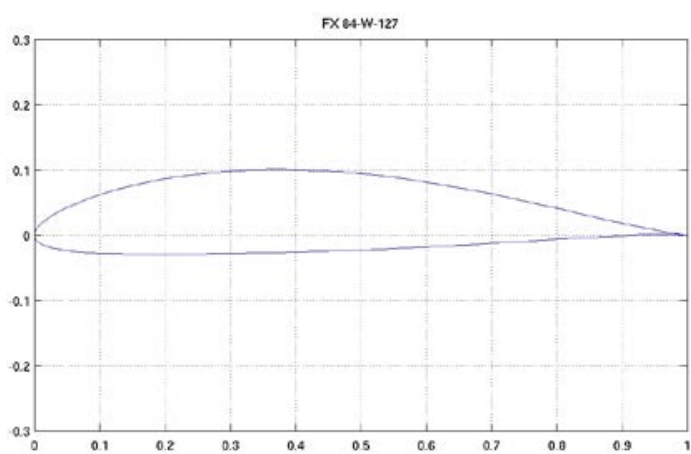

Gambar - 4. Airfoil Wortmann FX 84-W-127

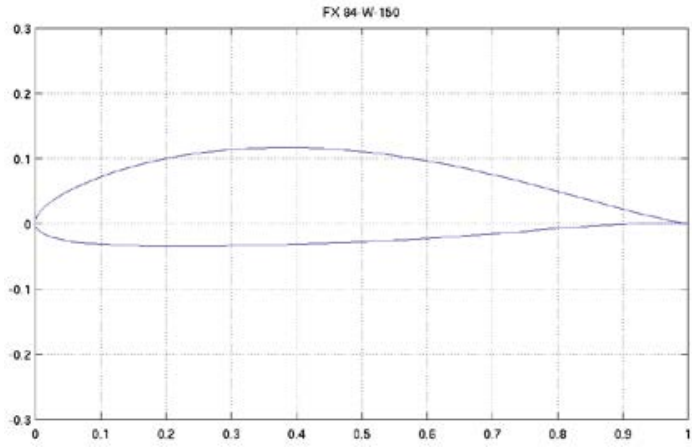

Gambar - 5. Airfoil Wortmann FX 84-W-150

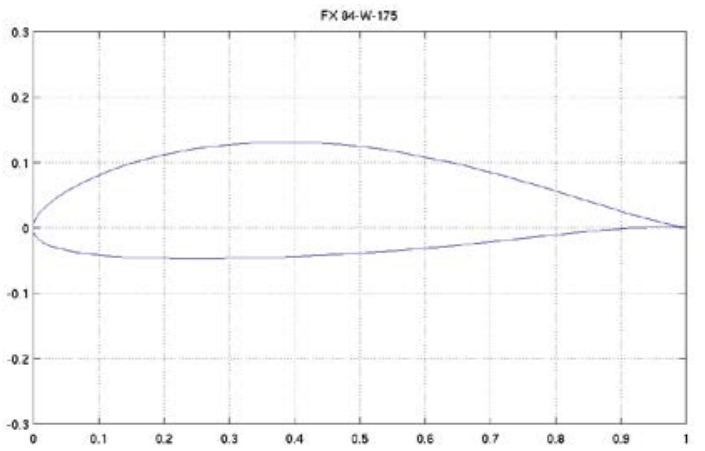

Gambar - 6. Airfoil Wortmann FX 84-W-150 


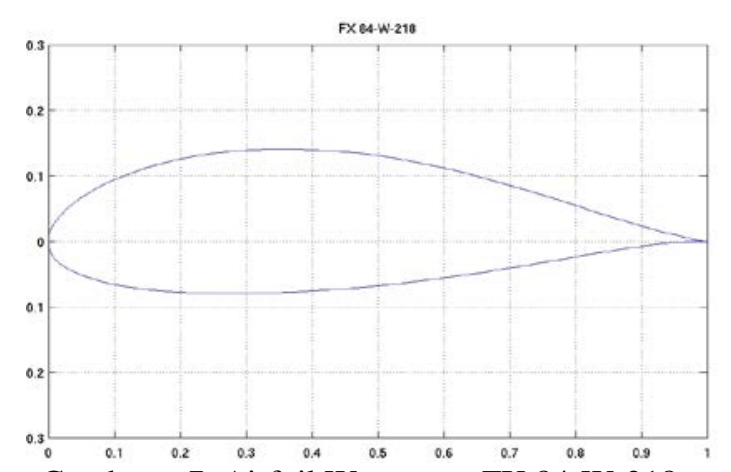

Gambar - 7. Airfoil Wortmann FX 84-W-218

Tabel - 2 Properties propeller berdasarkan hasil

\begin{tabular}{|c|c|c|c|c|}
\hline No & Jenis Airfoil & $\begin{array}{c}\text { Angle } \\
\text { of } \\
\text { Attack } \\
(\alpha)\end{array}$ & $\begin{array}{c}\text { Lift } \\
\text { Coeficie } \\
n t(C l)\end{array}$ & $\begin{array}{c}\text { Drag } \\
\text { Coefficie } \\
\text { nt (Cd) }\end{array}$ \\
\hline 1 & $\begin{array}{c}\text { Wortmann FX 84- } \\
\text { W-097 }\end{array}$ & 10 & 1.1750 & 0.04329 \\
\hline 2 & $\begin{array}{c}\text { Wortmann FX 84- } \\
\text { W-127 }\end{array}$ & 10 & 1.2882 & 0.02641 \\
\hline 3 & $\begin{array}{c}\text { Wortmann FX 84- } \\
\text { W-150 }\end{array}$ & 10 & 1.3108 & 0.03434 \\
\hline 4 & $\begin{array}{c}\text { Wortmann FX 84- } \\
\text { W-175 }\end{array}$ & 10 & 0.9592 & 0.07033 \\
\hline 5 & $\begin{array}{c}\text { Wortmann FX 84- } \\
\text { W-218 }\end{array}$ & 10 & 0.9010 & 0.05628 \\
\hline
\end{tabular}

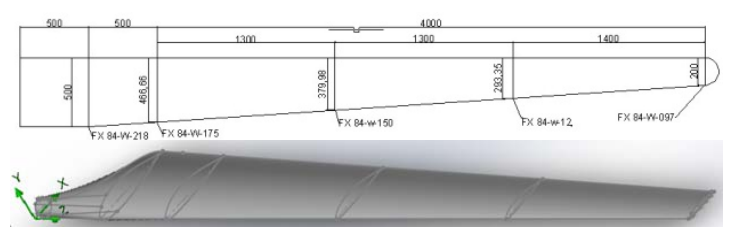

Gambar - 8. Propeller turbin angin

\section{Hasil Penelitian}

Dalam penelitian ini, lift yang dihasilkan oleh propeller digunakan untuk memutar poros, sementara drag menjadi beban bagi tower turbin berupa momen lengkung. Berdasarkan data yang ada menunjukan bahwa besar lift yang dihasilkan jauh lebih besar dibanding drag, dengan demikian besar torsi yang dihasilkan turbin akan lebih besar dibanding dengan beban yang akan diterima oleh tower.

Drag pada propeller cenderung konstan pada kecepatan angin $5 \mathrm{~m} / \mathrm{s}$ sampai dengan 8,5 $\mathrm{m} / \mathrm{s}$ sementara lift mengalami kenaikan di sepanjang variasi kecepatan udara mulai dari 5 $\mathrm{m} / \mathrm{s}$ hingga $8,5 \mathrm{~m} / \mathrm{s}$.

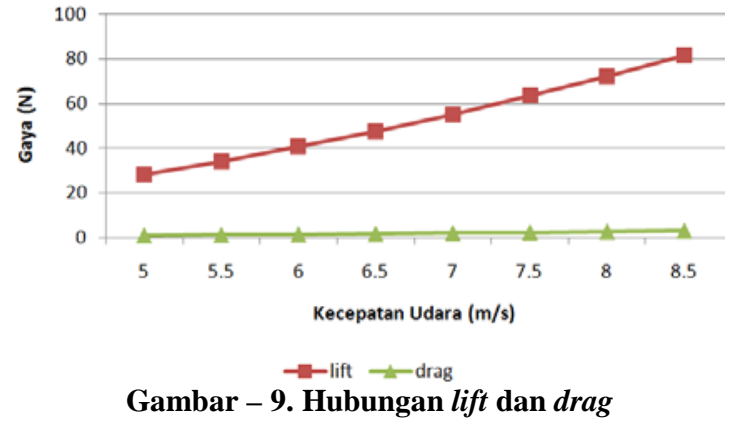

Torsi mengalami sedikit peningkatan pada perubahan kecepatan udara mulai $5 \mathrm{~m} / \mathrm{s}$ hingga $8,5 \mathrm{~m} / \mathrm{s}$, sementara torsi pada poros turbin angin dengan lima buah blade cenderung meningkat lebih besar pada kenaikan kecepatan udara mulai $5 \mathrm{~m} / \mathrm{s}$ sampai dengan $8,5 \mathrm{~m} / \mathrm{s}$.

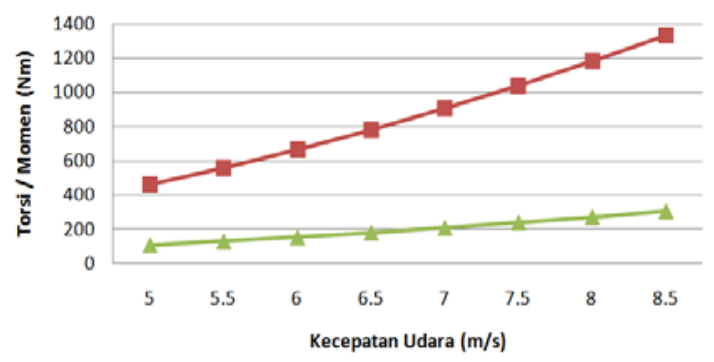

Gambar - 10. Hubungan torsi dan momen lengkung tiang

Pada variasi kecepatan udara $5-8,5 \mathrm{~m} / \mathrm{s}$, momen lengkung yang diterima oleh tiang penyangga turbin angin hanya sebesar 30,13\% dari momen puntir yang dihasilkan turbin. Pada kecepatan udara $5 \mathrm{~m} / \mathrm{s}$, torsi pada poros 70,899 $\mathrm{Nm}$, momen lengkung tiang penyangga 21,358 $\mathrm{Nm}$, sementara pada kecepatan udara $8 \mathrm{~m} / \mathrm{s}$ torsi pada poros 181,501 Nm, momen lengkung tiang penyangga $54,678 \mathrm{Nm}$.

\section{Kesimpulan}

Kesimpulan yang dapat ditarik dari penelitian ini adalah:

a. Besar torsi yang dihasilkan poros turbin lebih besar bila dibandingkan dengan momen lengkung yang diterima oleh tower tubin angin.

b. Torsi dan daya akan meningkat seiring dengan meningkatnya kecepatan angin yang melewati turbin.

c. Moment lengkung yang diterima oleh tower akan sedikit sekali mengalami peningkatan dan cenderung konstan. 
d. Walaupun kecepatan angin di Indonesia relativ rendah di sepanjang tahun, namun tetap dapat dimanfaatkan untuk membangkitkan listrik.

\section{DAFTAR PUSTAKA}

[1] Abbott, Ira H. \& Albert E Von Doenhoff. Theory of Wing Section. New York: Dover Publication Inc., 1958.

[2] BPPT, Outlook Energi Indonesia 2012. Jakarta: BPPT Press, 2012.

[3] DJLPE. 2005. Blueprint Pengeloaan Energi Nasional 2005-2010. Jakarta : Direktorat Energi dan SDM, 2005.

[4] Flavin, C. dan Lensson N. Gelombang Revolusi Energi. Jakarta: Yayasan Obor Indonesia, 1995.

[5] Hansen, Martin O. L. Aerodyanamic of Wind Turbine - Second Edition. United Kingdom dan USA: Earthscan, 2008.

[6] Djojodiharjo, Harijono. Aspek Tekno Ekonomi dari Pemanfaatan Energi Angin di Indonesia. Jakarta: LAPAN, 1980.

[7] Harika, Adam. 2008. Rancang Bangun Blade Pitch Angle Control System Berbasis Classicfuzzy pada Prototipe Wind Turbine. Surabaya : Institut Teknologi Sepuluh Nopember, 2008.
[8] Jansen, W. A. M. dan P. T. Smulders. Rotor Design for Horizontal Axix Windmills. Netherlands: Development Corporation Information Department, 1977.

[9] Nelson, Vaught. Wind Energy: Renewable Energy and the Enviorment. Taylor \& Francis Group, LCC, 2009.

[10] Piggot, Hugh. Wind Power Workshop. United Kingdom: Centre for Alternative Technology Publication, 2001.

[11] Tambunan, Robert Maraluli Tua. Perancangan dan Penbutan Turbin Angin Sumbu Horizontal Dua Sudu Berdiameter 3.5 m dengan Modifikasi Pemotongan dan Pengaturan Sudut Pitch. Bandung: Perpustakaan Digital ITB, 2008.

[12] Thumthae, $\mathrm{C}$ dan Chitsomboon, $\mathrm{T}$. Optimal Angle Of Attack For Untwisted Blade Wind Turbine. USA: The National Renewable Laboratory, 2009.

[13] W. Culp, Archie. Prinsip-prinsip Konversi Energi, Jakarta: Erlangga, 1996.

[14] WWEA, World Wind Energy Report 2010, Bonn: World Wind Energy Association, 2010. 